\title{
EFFECTS OF DIFFERENT CONCENTRATION OF POTASSIUM NITRATE ON BREAKING DORMANCY OF BLACK GRAM (VIGNA MUNGO L.)
}

\author{
N. VINOTHINI ${ }^{*}$, T. POOVARASAN ${ }^{2}$, R. K. BHAVYASREE ${ }^{3}$ \& KOTHAI SESHATHRI ${ }^{4}$ \\ ${ }^{1,}{ }^{4}$ Faculty of Agricultural Sciences, SRM Institute of Science and Technology, Deemed University, Kattankulathur,Tamil Nadu \\ India \\ ${ }^{2}$ Dept. of Seed Science and Technology, Tamil Nadu Agricultural University, Coimbatore, Tamil Nadu, India \\ ${ }^{3}$ Centre for Plant Breeding and Genetics, Tamil Nadu Agricultural University, Coimbatore, Tamil Nadu, India
}

\begin{abstract}
Black gram (Vigna mungo L.) is an important pulse crop grown in many parts of India. The demand for its seed is found throughout the year but it also undergoes dormancy which makes it difficult to cultivate as and when required. In this view, the experiment was conducted with different concentration of $\mathrm{KNO}_{3}$ to find out effective treatment for dormancy breaking in black gram. Seeds were treated with different concentration of $\mathrm{KNO}_{3}$ viz., 0.5, 1.0, 1.5, 2.0 and 2.5\% along with a control. The results revealed that black gram seeds treated with $1.0 \% \mathrm{KNO}_{3}$ show the highest germination per cent (90\%), maximum root length of $9.5 \mathrm{~cm}$ along with comparatively high shoot length. Vigour index was also high in treating with $1.0 \% \mathrm{KNO}_{3}$. Therefore, it can be concluded that black gram seeds with $1.0 \% \mathrm{KNO}_{3}$ found to be the most effective method for breaking the seed dormancy of black gram.
\end{abstract}

KEYWORDS: Black gram, dormancy, hard seeds, potassium nitrate, seed germination

Received: Nov 21, 2020; Accepted: Dec 12, 2020; Published: Jan 09, 2021; Paper Id.: IJASRDEC202010

\section{INTRODUCTION}

Black gram (Vigna mungo L.) is one of the most important pulse crops grown throughout India. Except in India, the primary origin of the crop, it is also cultivated in Asian countries including Pakistan, Myanmar and parts of Southern Asia (Singh and Ahlawat, 2005). The coastal region in Andhra Pradesh is famous for the black gram. The seeds contain a perfect combination of essential nutrients including about $26 \%$ protein, $60 \%$ carbohydrates, $1.5 \%$ fat along with good proportions of vitamins, amino acids, fibre and minerals (Hartmann et al., 1997). It is rich in vitamins like A, B complex and also vitamin C. It is a dual purpose kharif pulse crop which is also used as nutritive fodder for the milch animals. But in southern and South-eastern parts of India, it is grown in rice fallows and Rabi. It also helps in improving and sustaining the fertility status of the soil by influencing physical properties and atmospheric nitrogen fixation (Singh et al., 2015).

Seed dormancy is the condition in which the viable seed fails to germinate even under favourable condition (Bewley, 1997; Finch - Savage and Leubner-Metzger, 2006). The pulses seeds have the dormancy problem generally due to the covering structures present in the (Jackson and Blundell, 1963). In pulses, the hard seed is the major problem because such seeds fail in germination. In Black gram, which is one of the major pulses in the country, is found to have about 3-4 months of seed dormancy. So, the use of some chemicals like potassium nitrate $\left(\mathrm{KNO}_{3}\right)$ has been recommended for breaking seed dormancy and promoting seed germination. $\mathrm{KNO}_{3}$ is an effective chemical used for 
dormancy breaking and the presowing treatment with this chemical is generally carried out in seed testing laboratories (Olmez et al., 2004, Hartmann et al., 1997). Therefore, it was thought that treatment of black gram seeds primed with different concentrations of $\mathrm{KNO}_{3}$ may influence breaking seed dormancy, rapid germination and shoot, root establishment. Seed priming is a method to initiate the metabolic activities prior to germination and does not allow the actual radicle emergence by controlling hydration (Vinothini et al., 2020; Vinothini and Bhavyasree, 2019). Priming treatment enhances seed germination and other seedling parameters in black gram (Poovarasan et al., 2019). Therefore, an experiment was conducted using different concentrations of $\mathrm{KNO}_{3}$ to find the most effective concentration for breaking seed dormancy in black gram.

\section{MATERIALS AND METHODS}

\subsection{Collection of Seeds}

The experiment was conducted at Faculty of Agricultural Sciences, SRM Institute of Science and Technology, Deemed University, Kattankulathur, Tamil Nadu - 603 203, India. Freshly harvested and genetically pure black gram (cv. ADT 6) seeds were collected from the National Pulse Research Centre (NPRC), Vamban. Purpose of this study is to analyse the effect of different concentrations of $\mathrm{KNO}_{3}$ on breaking dormancy of black gram.

\subsection{Treatments}

Seeds were soaked with standardization of different concentration of $\mathrm{KNO}_{3}$ viz., $0.5 \%, 1.0 \%, 1.5 \%, 2.0 \%$ and $2.5 \%$ and along with control (non-treated seeds). Seeds were soaked in the solution for three hours, followed by rinsing in water and shade-drying at room temperature for $24 \mathrm{~h}$. Then following observation should be recorded such as germination per cent (\%), Seedling parameters including root length, shoot length and vigour index.

\subsection{Germination (\%)}

Germination percentage is an estimate of the viability of a population of seeds. Germination tests were conducted by roll towel method with 4 replications of 100 seeds in each treatment and kept in germination room at the temperature of $25 \pm 2$ ${ }^{\circ} \mathrm{C}$ and relative humidity of $95 \pm 2 \%$ was maintained. Seedlings were evaluated on the $7^{\text {th }}$ day like normal seedlings, abnormal seedlings, fresh un-germinated seeds, hard seed and dead seeds (ISTA, 2012). Based on the number of normal seedling present, the germination percentage was calculated by the following formula.

$$
\text { Germination } \%=\frac{\text { Number of normal seedlings }}{\text { Total number of seed sown }} \times 100
$$

\subsection{Root Length (cm)}

From each replication, ten seedlings were selected randomly and used for measuring the root length. The root length measured from collar to the tip of the root and it expressed in centimetre.

\subsection{Shoot Length (cm)}

The seedlings selected for root length measurement were used for obtaining shoot length. The length is measured from collar to the tip of the primary leaf and values expressed in centimetre.

\subsection{Vigour Index}

Vigour index of the seedlings was estimated as suggested by Abdul-Baki and Anderson (1973) and mean values were expressed in whole numbers. 
Vigour index $=$ Germination per cent $\mathrm{x}$ total seedling length $(\mathrm{cm})$

\section{RESULTS}

Treatments were significantly influenced all the physiological parameters. The observed results showed that when the seeds were treated with $1 \% \mathrm{KNO}_{3}$, the highest germination percentage $(90 \%)$ was obtained followed by $\mathrm{KNO}_{3} 0.5 \%$ and $1.5 \%$ ( 78 per cent) when compared to the control (26 per cent) which had the lowest germination per cent (Fig. 1).

Treatment with $\mathrm{KNO}_{3}$ at 1 per cent showed the maximum root length $(9.5 \mathrm{~cm})$ followed by $\mathrm{KNO}_{3} 1.5$ per cent $(9.2$ $\mathrm{cm})$. Minimum root length recorded in control seeds $(6 \mathrm{~cm})$ (Fig. 2).

The maximum shoot length $(25.6 \mathrm{~cm})$ was recorded when the seeds were treated with 1 per cent of $\mathrm{KNO}_{3}$ and comparatively, minimum shoot length was observed in $2.5 \%$ of $\mathrm{KNO}_{3}(22.5 \mathrm{~cm})$ followed by non-treated seeds $(18.1 \mathrm{~cm})$ (Fig. 3).

Similarly, the highest vigour index value (3159) was recorded in seeds treated with $1 \% \mathrm{KNO}_{3}$, while the lower vigour index of 627 was recorded by non-treated seeds (control) (Fig. 4). Therefore it can be concluded that treating the seeds with $1.0 \%$ of $\mathrm{KNO}_{3}$ was found to be most effective and could be recommended for breaking the seed dormancy of black gram.

\section{DISCUSSIONS}

The seed germination of 90 per cent was the highest among the treatments when the seeds were treated with $1 \%$ of $\mathrm{KNO}_{3}$. Imbibition of $1 \% \mathrm{KNO}_{3}$ for 24 hours during seed priming found to have positive effects in wheat seeds which resulted in enhanced germination per cent as per the reports of Abnavi and Ghobadi (2012).Hegazi et al. (2011) found that $\mathrm{KNO}_{3}$ may also serve as a nutrient source. Similar reports were there in sorghum also by Shehzad et al. (2012) with $1 \% \mathrm{KNO}_{3}$. Futhermore, the treatment of $1 \% \mathrm{KNO}_{3}$ for 24 hours in soybean improved the germination percentage of primed seed when compared with non-primed seed in both laboratory and field conditions (Mohammadi, 2009). Cirak et al. (2004) reported that $\mathrm{KNO}_{3}$ improved the seed germination of many plant seeds. The maximum root length was observed when seed treated with $1 \%$ of $\mathrm{KNO}_{3}$ with shoot length comparatively. Yazdanshenas et al. (2015) observed that $\mathrm{KNO}_{3}$ treatment performs as a food supplement and a significant increasing in root and shoot growth. In corn, Nezhad et al. (2013) observed that the speed of germination based on mean germination time was also found to be increased by seed priming with $1 \% \mathrm{KNO}_{3}$ at 24 hours. Cavusoglu et al. (2017) observed that $\mathrm{KNO}_{3}$ may show different effects on seed germination and seedling growth depending on the plant species and the concentration used. The vigour index was also recorded more in seed treated with $1 \%$ of $\mathrm{KNO}_{3}$. Ruttanaruangboworn et al. (2017) reported that rice seed priming with $1 \% \mathrm{KNO}_{3}$ increased seed vigour in terms of the speed and uniformity of germination showing its effectiveness resulting highest germination percentage. Bhavyasree and Vinothini (2019) reported that seed factors along with the environmental factors are influencing the germination percentage, initial vigour of the seedling, plant population per unit area, yield and productivity.

\section{CONCLUSIONS}

The present study showed that black gram seeds soaked with $1.0 \% \mathrm{KNO}_{3}$ recorded highest germination percentage (90\%), maximum root length of $9.5 \mathrm{~cm}$ along with comparatively high shoot length. Vigour index was also high when treating with $1.0 \% \mathrm{KNO}_{3}$. Therefore, it can be concluded that for best germination percentage of black gram, $1.0 \% \mathrm{KNO}_{3}$ could 
be recommended for dormancy breaking treatment for black gram seeds.

1. Abdul-Baki, A. A., \& Anderson, J. D. (1973). Vigor determination in soybean seed by multiple criteria 1. Crop science, 13(6), 630-633.

2. Abnavi, M. S., \& Ghobadi, M. (2012). The effects of source of priming and post-priming storage duration on seed germination and seedling growth characteristics in wheat (Triticum aestivem L.). Journal of Agricultural Science, 4(9), 256.

3. Bewley, J. D. (1997). Seed germination and dormancy. Plant Cell, 9, 1055-1066.

4. Bhavyasree, R. K., \& Vinothini, N. (2019). Enhancement of seed quality through orgopriming in brinjal (Solanum melongena L.). International Journals of Chemical Studies, 7(1), 242-244.

5. Cavusoglu, K. et al (2017). Role of Potassium Nitrate ( $\left.\mathrm{KNO}_{3}\right)$ in Alleviation of Detrimental Effects of Salt Stress on Some Physiological and Cytogenetical Parameters in Allium cepa L. Cytologia, 82(3), 279-286.

6. Cirak, C. et al (2004). The effects of light and some presoaking treatments on germination rate of st. John's worth (Hypericum perforatum L.) seeds. Pakistan Journal of Biological Sciences, 7, 182-186.

7. Finch - Savage, W. E., \& Leubner - Metzger, G. (2006). Seed dormancy and the control of germination. New phytologist, 171(3), 501-523.

8. Hartmann, H. T. et al (1997). Plant propagation principles and practices. Sixth edition. New Jersey, Prentice Hall, USA.

9. Hegazi, E. S. et al (2011). Effect of potassium nitrate on vegetative growth, nutritional status, yield and fruit quality of olive cv. Picual. J. Hort. Sci. Ornament Plants, 3, 252-258.

10. ISTA. (2012). International rules for seed testing. Bassersdorf (Switzerland): International Seed Testing Association.

11. Jackson, G. A. D., \& Blundell, J. B. (1963). Germination in Rosa. Journal of Horticultural Science, 38(4), 310-320.

12. Mohammadi, G. R. (2009). The effect of seed priming on plant traits of late-spring seeded soybean (Glycine max L.). American-Eurasian Journal of Agricultural and Environmental Science, 5(3), 322-326.

13. Nezhad, R. R. et al (2013). The effects of priming on some qualities of seed germination. International Journal of Agriculture and Crop Sciences, 5(22), 2732-2735.

14. Olmez, Z. et al (2004). Effects of $\mathrm{H}_{2} \mathrm{SO}_{4}, \mathrm{KNO}_{3}$, and $\mathrm{GA}_{3}$ treatments on germination of caper (Capparis ovata Desf.) seeds. Pakistan Journal of Biological Sciences, 7, 879-882.

15. Poovarasan, T. et al (2019). Seed quality improvement with fruit extracts in black gram. Journal of Phytology, 16-20.

16. Ruttanaruangboworn, A. et al (2017). Effect of seed priming with different concentrations of potassium nitrate on the pattern of seed imbibition and germination of rice (Oryza sativa L.). Journal of Integrative Agriculture, 16(3), 605-613.

17. Shehzad, M. et al (2012). Influence of priming techniques on emergence and seedling growth of forage sorghum (Sorghum bicolor L.). Journal of Animal and Plant Sciences, 22(1), 154-158.

18. Singh, A. K. et al (2015). Pulses production in India: Present status, sent status, bottleneck and way forward. Journal of Agri Search, 2(2), 75-83.

19. Singh, D. P. \& Ahlawat, P. S. (2005). Greengram (Vigna radiata) and Black gram (Vigna mungo) improvement in India: Past, Present and Future prospects. Indian Journal of Agricultural Sciences, 75(5), 243-250. 
20. Vinothini, N. et al (2020). Seed priming to mitigate the impact of elevated carbon dioxide associated temperature stress on germination in rice (Oryza sativa L.), Archives of Agronomy and Soil Science, 66(1), 83-95.

21. Vinothini, N., \& Bhavyasree, R. K. (2019). Orgopriming to enhance seed germination in groundnut. Research Journal of Agricultural Sciences, 10(1), 231-233

22. Yazdanshenas, H. et al (2015). Effect of different physicochemical treatments on seed dormancy of medicinal herbs (Portulaca oleracea L.). Research Journal of Medicinal Plant, 9, 72-80.

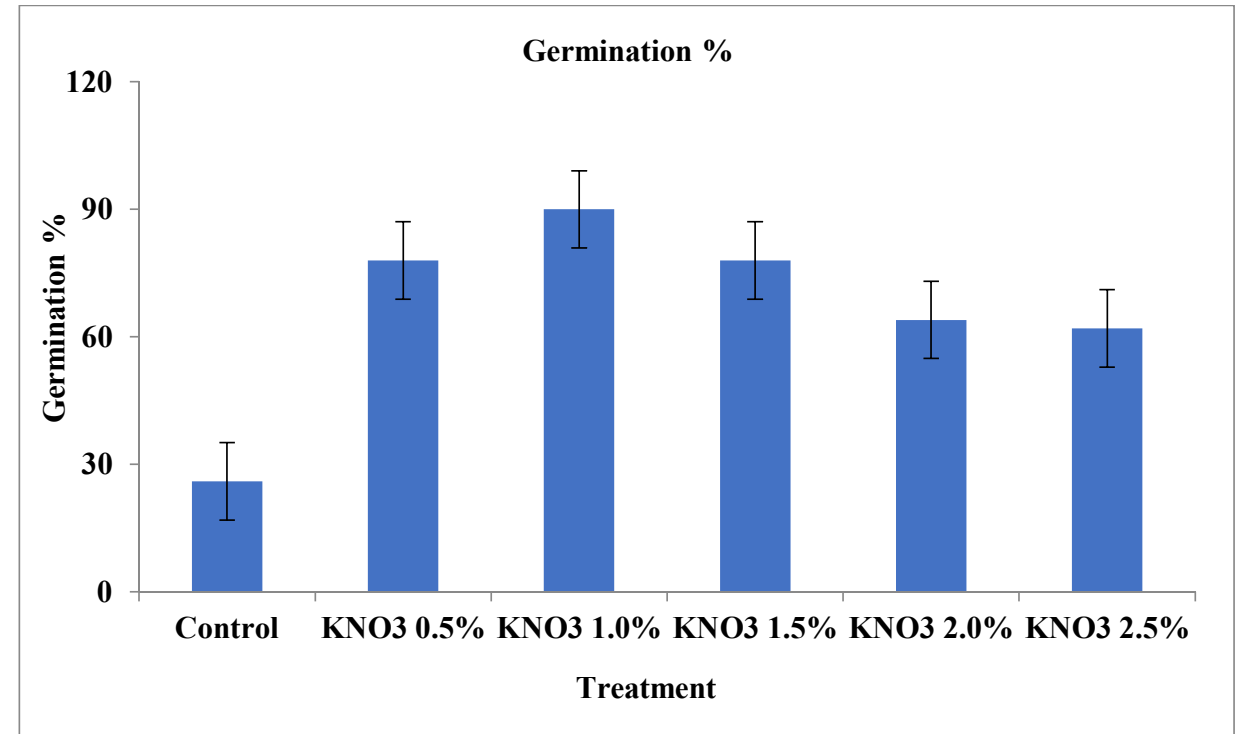

Figure 1: Effect of different concentrations of $\mathrm{KNO}_{3}$ on seed germination

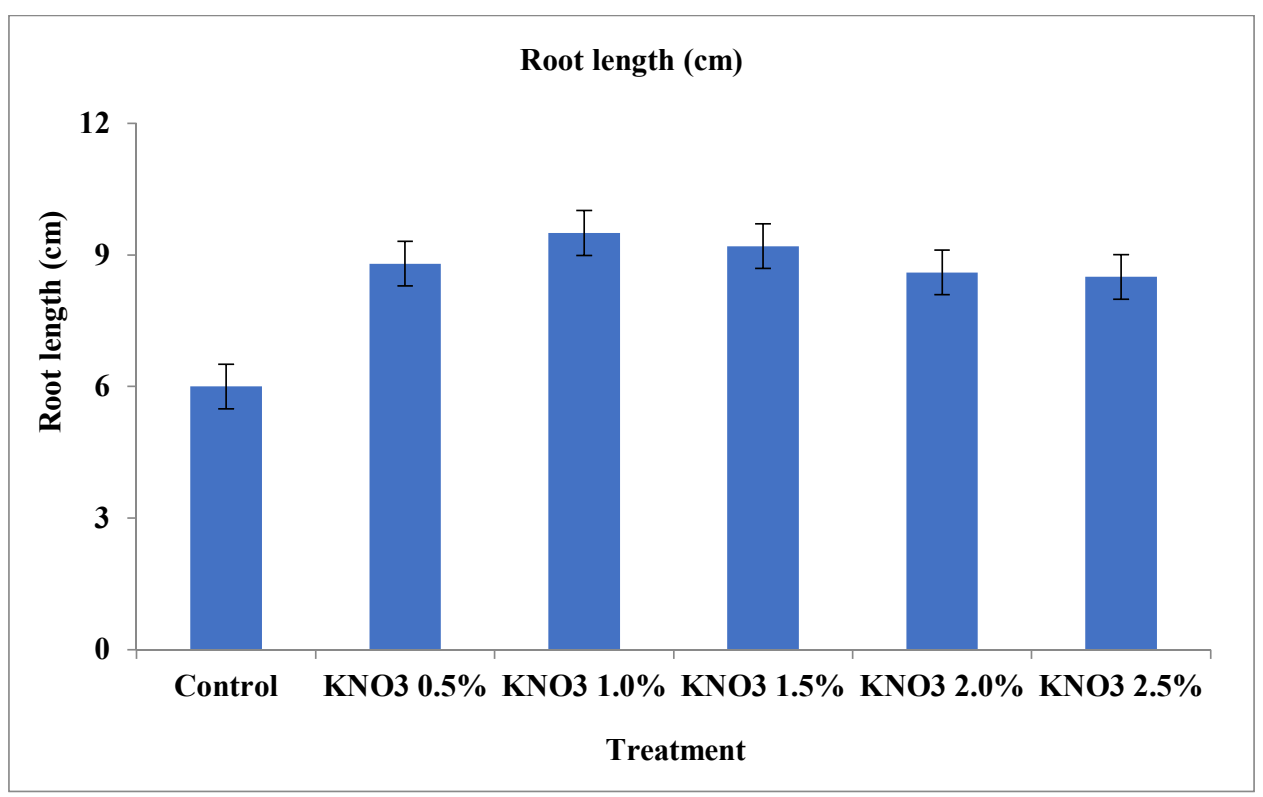

Figure 2: Comparison of root length on different treatments of $\mathrm{KNO}_{3}$ 


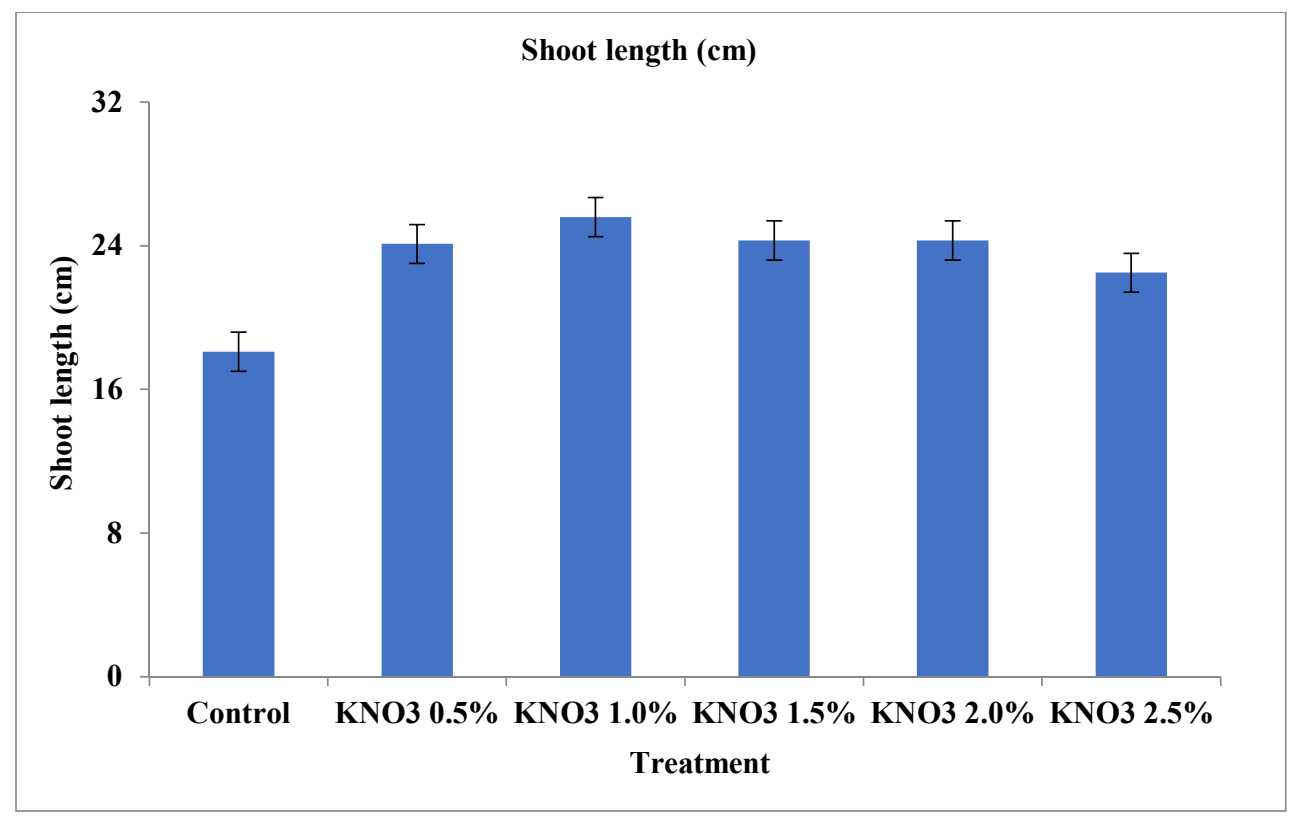

Figure 3: Comparison of shoot length on different treatments of $\mathrm{KNO}_{3}$

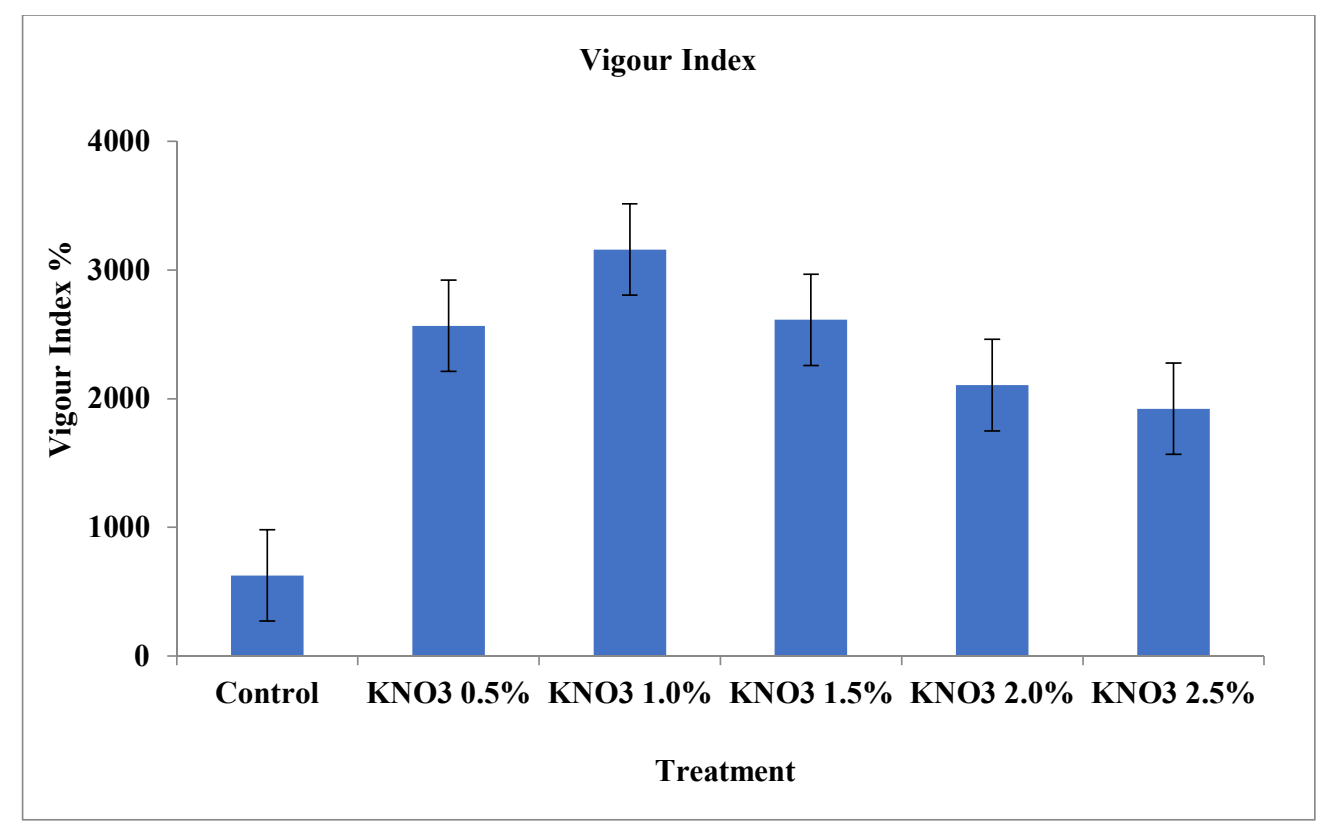

Figure 4: Effect of different concentrations of $\mathrm{KNO}_{3}$ on vigour index 